\title{
Genetic kidney diseases
}

\author{
Friedhelm Hildebrandt \\ Howard Hughes Medical Institute and Departments of Pediatrics and of Human Genetics, \\ University of Michigan, Ann Arbor, Michigan 48109, USA
}

\section{Abstract}

Knowledge of the primary cause of a disease is essential for understanding its mechanisms and for adequate classification, prognosis, and treatment. Recently, the etiologies of many kidney diseases have been revealed as single-gene defects. This is exemplified by steroid-resistant nephrotic syndrome, which is caused by podocin mutations in $~ 25 \%$ of childhood and $\sim 15 \%$ of adult cases. Knowledge of a disease-causing mutation in a single-gene disorder represents one of the most robust diagnostic examples of "personalized medicine", because the mutation conveys an almost $100 \%$ risk of developing the disease by a certain age. Whereas single-gene diseases are rare disorders, polygenic "risk alleles" are found in common adult-onset diseases. This review will discuss prominent renal single-gene kidney disorders and polygenic risk alleles of common disorders. We delineate how emerging techniques of total exome capture and large-scale sequencing will facilitate molecular genetic diagnosis, prognosis and specific therapy and lead to a better understanding of disease mechanisms, thus enabling development of new targeted drugs.

\section{Genetic causality and predictive power of mutation analysis}

In single-gene disorders, which are also known as "monogenic diseases", a mutation of a single gene (out of the total of $\sim 25,000$ genes) is sufficient to cause the disease. Conversely, in polygenic disorders mutations of multiple different genes are necessary to result in a disease. The degree of genetic causality varies with the mode of inheritance (Table 1). At one end of the spectrum there is tight genotype-phenotype correlation in monogenic recessive diseases, where the disease phenotype is almost exclusively determined by the single-gene causative mutation in way of "full penetrance" with a very high predictive power of mutation analysis (Table 1). Recessive diseases usually manifest prenatally, in childhood or in adolescence. Dominant diseases manifest typically in adults (e.g., in autosomal dominant polycystic kidney disease) (Table 1). Their tightness of genotypephenotype correlation is somewhat reduced when compared to recessive diseases, because they may exhibit incomplete penetrance (i.e., skipping of the disease phenotype in a generation) and variable expressivity (i.e., varying degrees of organ involvement), as for instance in glomerulocystic kidney disease (GCKD).

Correspondence should be addressed to: Friedhelm Hildebrandt, M.D., Howard Hughes Medical Institute, Departments of Pediatrics and of Human Genetics, University of Michigan Health System, 8220C MSRB III, 1150 West Medical Center Drive, Ann Arbor, MI 48109-5646, USA, Phone: +1 734 615-7285 (office), +1 734 615-7895, -7896 (laboratories), Fax: +1 734-615-1386, -7770, fhilde@umich.edu.

Search strategy and selection criteria

This review is based on an ongoing review of the literature over the last 10 years pertaining to genetic kidney diseases. We searched PubMed for review articles on the terms [kidney AND "molecular genetics"]. In addition, we searched OMIM

(http://www.ncbi.nlm.nih.gov/sites/entrez) for "renal tubular + \#”. Recent review articles on the topic were taken into consideration.

Conflict of interest statement

The author declares no conflict of interest. 
At the other end of the spectrum of causality are polygenic diseases, in which genotypephenotype correlation is very weak (Table 1), and usually only a relative risk can be assigned to a genetic change, as for instance in an association between makers of the MYH9 locus and focal segmental glomerulosclerosis (see below). Polygenic diseases usually manifest in adulthood and are much more frequent than monogenic diseases. As they show less heritability they leave more room for environmental influences. Risk alleles in polygenic diseases are usually derived from genome-wide association studies (Table 1)(1).

\section{Mutation analysis in single-gene kidney diseases}

Due to the strong genotype-phenotype correlation of almost $100 \%$ that is seen in recessive single-gene renal disorders (Table 1), mutation analysis in these diseases reveals the primary cause of the disease, permits prenatal diagnostics, and has a very high diagnostic and prognostic value. Identification of a mutation in a known recessive disease gene may be viewed as probably the most robust diagnostic example of "personalized medicine", because the recessive mutation conveys an almost $100 \%$ risk that the patient will develop the respective disease by the end of adolescence, as for example in autosomal recessive polycystic kidney disease (ARPKD). When performing molecular genetic diagnostics, genes are examined for disease-causing DNA sequence changes. Mutation analysis is usually performed by PCR of exons followed by direct exon sequencing, as it is estimated that about $85 \%$ of all disease-causing mutations in single-gene disorders are positioned within a coding exon.

Mutation analysis in single-gene renal disorders requires informed consent and submission of a blood sample from the affected individual for DNA extraction. Multiple web sites identify non-commercial research laboratories that offer mutation analysis, often in conjunction with interpretation of results (www.genetests.org, www.renalgenes.org). Given the potential ethical, legal, emotional and economic consequences that may result from molecular genetic diagnostics, the request should ideally be initiated from a genetic counseling session, in which the patient (and/or parents in childhood cases) receives counseling by a certified genetic counselor.

Tables 2-6 provide an overview on single-gene renal diseases, for which molecular genetic diagnosis is available. Usually, molecular genetic diagnosis is sought to clarify the etiology of a rare disease that is otherwise difficult to diagnose. To aid in the selection of target genes for molecular genetic diagnosis kidney diseases are grouped by leading diagnostic feature (Tables 2-6).

\section{In glomerular diseases mutations determine age of onset and treatment response}

The leading diagnostic feature of renal glomerular diseases is proteinuria. Steroid-resistant nephrotic syndrome (SRNS), which typically manifests histologically as focal segmental glomerulosclerosis (FSGS), remains one of the most intractable kidney diseases. In children it carries a $30 \%$ risk of recurrence in a kidney transplant. Multiple single-gene causes of SRNS have been identified (Table 2)(2). Recessive mutations in NPHSI (nephrin) cause congenital nephrotic syndrome with onset by 90 days of life(3). Mutations of NPHS2 (podocin)(4) cause 10-28\% of all non-familial childhood SRNS cases (Table 2)(5). With very few exceptions, all monogenic forms of SRNS lead to chronic kidney disease (CKD)(6) and are resistant to steroid treatment.

There is a strong correlation between causative gene mutations and the age of onset of FSGS or CKD in at least two ways: (1) Mutations in different genes SRNS with onset at different 
ages. For instance, mutations in NPHS1 (nephrin), NPHS2 (podocin), LAMB2 (laminin- $\beta 2$ ), and PLCE1 (phospholipase C epsilon 1) cause childhood onset SRNS, whereas the rare mutations in dominant genes, including actinin- $\alpha 4$ (ACTN4), TRPC6 lead to adult onset disease $(7,8)$ with few exceptions(9) (Table 2). The earlier the onset of SRNS, the more likely it is of monogenic origin (Table 1). This is exemplified by the fact that $85 \%$ of all SRNS that manifests in the first 3 months of life and $66 \%$ of all SRNS manifesting in the first year of life are caused by mutations in one of only four genes, NPHS1, NPHS2, $L A M B 2$, or $W T 1(10)$. (2) For recessive podocin mutations, the combination of the two parental alleles determines age of onset of SRNS and end-stage renal failure (ESRF)(11). Specifically, the presence of at least one truncating mutation of the mutation "R138Q" leads to early onset of SRNS at a median age of 1.7 years rather than 4.7 years(11). Recently, it was shown that compound heterozygosity for the R229Q variant of podocin and one "bona fide" podocin mutation causes adult onset in up to $15 \%$ of SRNS cases(12). In childhood nephrotic syndrome an important correlation between genotype and treatment response has been revealed, in that patients with two recessive mutations of the podocin gene do not respond to standard steroid treatment but have a strongly reduced likelihood of FSGS recurrence in a renal transplant $(35 \%$ vs. $8 \%)(13,14)$.

\section{Renal cystic "ciliopathies" exemplify mechanisms of genotype-phenotype correlation}

Autosomal dominant polycystic kidney disease (ADPKD) is the most frequent lethal dominant disease in the United States and Europe, afflicting about 1 in 1,000 individuals(15). CKD develops by age $60-70$ years. The two genes mutated in ADPKD, $P K D 1$ and $P K D 2$, encode polycystin 1 and polycystin 2, which play a role in the maintenance of renal tubular cell differentiation (Table 3)(16). Although ADPKD1 and ADPKD2 mutations segregate in families in an autosomal dominant way, the cellular defect leading to renal cysts is most likely recessive on the basis of "second hit" mutations that occur throughout life in certain renal tubule cells thereby inducing cysts growth(17). Whereas molecular genetic diagnostics have been technically very difficult until recently, up to $90 \%$ of cases with ADPKD can now be diagnosed, which is very helpful for clinical decision making, especially regarding living related donor transplantation.(18)

Autosomal recessive polycystic kidney disease (ARPKD) is characterized by bilateral renal cystic enlargement that may start in utero. CKD develops directly postnatally, or in childhood or adolescence, depending on the severity of the two recessive mutations in the causative PKHD1 gene (Table 3). Intrahepatic bile duct dysplasia causes chronic liver fibrosis with abnormal bile duct structure (Caroli's disease). The presence of truncating mutations in PKHDI is associated with perinatal onset of ARPKD.

Nephronophthisis (NPHP) is the most frequent genetic cause for CKD in the first three decades of life (19-21). CKD develops by at a median age of 13 years. In contrast to PKD, cysts are mostly restricted to the corticomedullary border of the kidneys, and kidney size is normal or reduced. Mutations in nine different recessive genes (NPHPI-NPHP9) have been identified as causing NPHP (Table 3)(22-31). It can be associated with retinal degeneration (Senior-Loken syndrome, SLSN), liver fibrosis, or cerebellar vermis aplasia (Joubert syndrome, JBTS). Bardet-Biedl syndrome(32) is an autosomal recessive multi-system disorders that is characterized by the cardinal features of retinitis pigmentosa, polydactyly, mental retardation, hypogenitalism and obesity $\left(33^{-} 42\right)$.

A unifying pathogenic concept for cystic kidney diseases was recently developed from the discovery that all gene products that if mutated cause cystic kidney disease (e.g., ARPDK, ARPKD, NPHP, BBS) are expressed at the "primary cilia/centrosome complex"(43). 
Centrosomes, who convert into the spindle poles during mitosis, play an important role in cell cycle regulation and assembly of sensory cilia. This has lead to a pathogenic concept that summarizes the cystic kidney diseases ADPKD, ARPKD, NPHP, Meckel-Gruber syndrome, BBS and others as "renal cystic ciliopathies" $\left(44^{-} 46\right)$. The current mechanistic concept of renal cyst development holds that during renal morphogenesis, when renal tubules normally elongate, malorientation of the mitotic spindle causes dilation rather than elongation and thereby cystic widening of tubules $(16,47)$.

In NPHP the nature of the two recessive mutations determines severity and extent of organ involvement, leading to seemingly different disorders. Within this varied genotypephenotype correlation loss-of-function mutations cause severe, early-onset, dysplastic, multiorgan disease (Meckel-Gruber syndrome), whereas reduced function mutations cause mild, late-onset, degenerative disease with limited organ involvement (NPHP with retinal degeneration). More specifically, the extent and severity of organ involvement, are determined by the following three genetic mechanisms:

1. Specific genes. Different genes cause different severity of phenotypes.

2. Multiple allelism. Whereas 2 truncating mutations of NPHP3, NPHP6 or NPHP8 cause Meckel-Gruber syndrome (Table 3), the presence of at least 1 missense mutation may lead to a "rescue" towards the milder phenotype of Joubert syndrome with involvement of kidney, eye and cerebellum.

3. Modifier genes. In homozygous NPHP1 deletions the presence of an additional heterozygous mutation in NPHP6 or NPHPS may cause additional eye or cerebellar involvement $(48,49)$. "Oligogenic" modifier effects have initially been demonstrated in BBS(50). However, the importance of modifier alleles within the concept of "oligogenicity" will have to be solidly founded on the basis of animal models before conclusions on its clinical impact can be drawn. Taken together, in renal cystic ciliopathies gene identification has allowed profound insights into its pathogenesis, which has recently spurned therapeutic trials in ADPKD.(17)

Finally, multiple benign and malignant tumors of the kidney can be caused by single-gene defects including mutations in TSC1, TSC2, VHL, WT1 and the MET protooncogen (Table 3) (51), and molecular genetic diagnostics play an important role for prevention in kindred in whom mutations in these genes segregate.

\section{Many renal tubular disorders allow unequivocal genetic diagnostics}

Renal tubular function governs reabsortion of water and solutes from the golmerular filtrate. An increasing number of tubulopathies are being recognized as caused by single-gene mutations (Table 4). For some diseases, such as Bartter syndrome, similar disease phenotypes may be caused by mutations in different genes $\left(52^{-} 57\right)$. The single-gene basis of renal tubulopathies allows for unequivocal molecular genetic diagnosis.

In renal tubulopathies the primary genetic defect causes loss of function of a specific renal transport protein or signaling molecule. As certain transport systems are expressed in specific tubule segments, clinical and diagnostic features allow focussing genetic diagnosis on genes expressed in those tubule segments. Consequently, functional disturbances of certain tubule segments lead to the folllowing defects of tubular reabsorption (Table 4): Proximal tubular defects cause glucouria, phosphaturia, aminoaciduria and/or proximal renal tubular acidosis (RTA). This combination of features is known as ,renal Fanconi syndrome“. Dysfunction of sodium reabsorption in the thick ascending limb of Henle's loop causes Bartter syndrome, renal salt loss and secondary hypokalemic metabolic alkalosis. Defects of the distal convoluted tubule cause Gitelman syndrome(58) and other forms of 
hypomagnesemia $\left(59^{-} 61\right)$. Tubulopathies of the collecting duct impair reabsorption of water, sodium, potassium and protons, resulting in polyuria, salt loss, hyperkalemia, and acidosis, respectively. Mutations in the aquaporin-2 water channel AQP2(62) cause recessive nephrogenic diabetes insipidus (NDI), and mutations in the vasopressin-2-receptor cause Xlinked NDI (Table 4) $(63,64)$. In secondary tubulopathies the genetic defect does not directly affect a tubular transport or transport signaling protein, but rather unspecifically leads to damage of renal tubule cells and thereby to renal tubular dysfunction (Table 4). Gene identification has rendered the often enigmatic disease group of tubulopathies accessible to unequivocal diagnostics.

\section{Nephrolithiasis}

Multiple single-gene causes of nephrolithiasis have been identified (Table 5)(65). Many of them represent rare abnormalities of specific renal tubular transport channels and transporters. Whether "mild" mutations in these genes may represent alleles conveying an increased risk for nephrolithiasis is currently unclear. This question may find an answer once exome capture and large-scale sequencing data have become available from large numbers of patients with nephrolithiasis (see below).

\section{Congenital abnormalities of the kidney and urinary tract (CAKUT)}

Congenital abnormalities of the kidney and urinary tract (CAKUT) account for approximately $50 \%$ of children with end-stage kidney disease. CAKUT occur in about 3 to 6 per 1,000 live births and constitute $20-30 \%$ of all anomalies identified in the neonatal period $(66,67)$. Single-gene mutations in many different genes (Table 6) may cause a wide phenotypic spectrum of CAKUT(68). Disease phenotypes include renal agenesis(69,70), renal hypodysplasia(71), multicystic/dysplastic kidney(72), hydronephrosis, ureteropelvic junction obstruction, megaureter, ureter duplex or fissus, prevesical stenosis, and vesicoureteral reflux(73-77) (Table 6). CAKUT may present as an isolated feature or as part of clinical syndromes $\left(78^{-} 80\right)$ in association with extrarenal manifestations as for example in branchio-oto-renal syndrome(81-83) or Kallman syndrome(84).

The pathomechanistic basis of CAKUT lies in the disturbance of normal nephrogenesis(85) $(86,87)$. Mutations in genes that govern nephrogenesis may cause CAKUT. Not surprisingly, many of the CAKUT-causing genes encode transcription factors $\left(88^{-} 90\right)$, which partially may explain the variable expressivity. The near future will probably reveal that most forms of CAKUT are due to a multitude of rare single-gene defects, which will allow important advances for preventive diagnostics.

\section{Gene identification informs diagnostics, therapy, and pathogenesis}

A very important feature of monogenic diseases is the fact that the mutation in itself represents the primary cause (etiology) of the disease. This provides the following opportunities for diagnostics, therapy, and insights into pathogenesis: i) Unequivocal molecular genetic diagnostics can be performed to avoid invasive procedures, e.g. the diagnosis of nephronophthisis can be made without the necessity for renal biopsy. ii) Prenatal diagnosis is possible, e.g. for diagnostics of the perinatal lethal Meckel-Gruber syndrome. iii) Specific prognostic outcomes can be delineated for specific mutations, e.g. in mutations of $P K D 1$ or $P K D 2$, which cause earlier or later onset of autosomal dominant polycystic kidney disease, respectively. iv) Subgroups of diseases may be classified for differential therapy, e.g. in mutations in NPHS2, which convey resistance to steroid treatment in nephrotic syndrome. v) Disease mechanisms (pathogenesis) can be studied in related monogenic animal models, e.g. in cystic kidney diseases, in which mouse models 
offered the first insights into disease mechanisms of renal cystic ciliopathies. vi) New drugs can be developed, for example by studying knockout animal models.

\section{Risk alleles in common and polygenic renal disorders}

In single-gene disorders the penetrance, i.e. the predictive value of mutations for the disease to manifest is close to $100 \%$ (Table 1), with the exception of age-dependent penetrance and, in dominant diseases with the exceptions of incomplete penetrance (skipping of a generation) and variable expressivity (different extent and severity of organ involvement). In contrast, in polygenic diseases multiple mutated alleles in different genes have to act in concert to cause disease (Table 1).

Recently, the clear-cut lines between single-gene (Mendelian) diseases and polygenic diseases have become somewhat blurred: In the examples of Bardet-Biedl syndrome(91) and nephronophthisis(49) modifier gene effects have been demonstrated. For example, most patients with complete absence of NPHPI function due to homozygous deletions of the NPHP1 gene (Table 3) develop isolated nephronophthisis only. However, the presence of a heterozygous mutation in NPHP6 causes in these patients the additional disease phenotypes of retinal degeneration or ataxia(92). In this context the heterozygous mutation in NPHP6 is considered to exert a "modifier gene" effect on NPHPI, because a heterozygous mutation alone in the recessive gene NPHP6 does not elicit a disease phenotype.

Disease-causing genes of single-gene disorders are rare, exert strong causality on the disease phenotype with (almost) full penetrance, manifest early in life, leave little room for environmental influences, and are usually detected by linkage mapping (Table 1). In contrast, polygenic disorders are more common, exert weak causality on the disease phenotype, manifest later in life, leave more room for environmental influences, and are usually detected by "genome-wide association studies (GWAS) (Table 1). In comparison between gene identification of single-gene disorders by linkage mapping and of polygenic disorders by GWAS, the latter offer the advantage that common (rather than rare) disease genes may be identified, but they also carry the disadvantage that GWAS often only explains a few percent of the variance of the phenotype, and that it is often difficult to assign an associated marker allele mechanistically to loss of function of a specific gene(1).

An example of successful identification of disease risk alleles in kidney diseases is the identification of specific haplotypes in the MYH9 locus that were found to be associated with an increased risk for focal segmental glomerulosclerosis (FSGS) and CKD in African American patients $(93,94)$. About $60 \%$ of the African American population in the US (compared to $4 \%$ of European Americans) carry this risk allele, and the risk of developing FSGS is increased 5-fold. Whether this incomplete penetrance of the risk allele is due to other polygenic influences or mostly goverened by environmental factors will have to be established. In addition, variants of the ELMOI (engulfment and cell motility 1) gene have been associated with type 2 diabetes-associated nephropathy(95).

For the global phenotype of chronic kidney disease (CKD) a risk association was demonstrated for the $U M O D$ gene, which causes autosomal dominant medullary cystic kidney disease type 2 (Table 3), when Koettgen et al. identified a polymorphic SNP (rs 12917707) near the UMOD locus as strongly associated with CKD(96). Furthermore, risk allele associations have been described for hypertension (OMIM \#145500), atypical hemolytic uremic syndrome (\#235400) and for the ATGR2 locus in ureteropelvic junction obstruction (\#145500). 


\section{Future directions}

For the approximately 5,400 known Mendelian disorders in humans the causative genes have been identified in only about 2,600, whereas in approximately 2,800 the diseasecausing gene is still elusive. Very recently, two novel techniques were developed that may significantly facilitate rapid discovery of causative genes for single-gene disorders. One of these techniques is "total human exome capture", which describes the ability to "capture" by hybridization the entire "exome" of all 180,000 protein-encoding human exons(97). Exome capture is followed up with another technique, "large-scale sequencing" (also known as "next-generation sequencing"). As there are estimates that about $85 \%$ of all disease-causing mutations in Mendelian disorders are positioned within coding exons, exome capture with consecutive large-scale sequencing will strongly accelerate disease gene discovery in the near future. This approach will further facilitate molecular genetic diagnosis, enhance our understanding of disease mechanisms, thus enabling development of new targeted drugs. It will also provide guides for mutation-specific prognosis and therapy. However, modern techniques of exome capture and large-scale sequencing will produce a high number of sequence variants, which renders identification of the true disease-causing mutation difficult. Therefore, it will become increasingly important that molecular genetic diagnostics are driven by leading clinical features (Tables 2-6) that generate candidate genes to be evaluated preferentially for disease-causing mutations.

In summary, novel molecular genetic techniques will rapidly provide deep novel insights into kidney diseases, especially regarding their diagnosis, nosologic classification, mechanistic understanding, recapitulation in animal models, and development of new therapeutics. The power of molecular genetic diagnosis will require solid implementation of genetic counseling and equitable access to these new opportunities for patients with kidney diseases.

\section{Acknowledgments}

This work was supported by grants from National Institutes of Health to F.H. (DK076683, DK1069274, DK1068306, DK064614, DK045345, and RC1-DK086542) and the Thrasher Research Fund. F.H. is an Investigator of the Howard Hughes Medical Institute, a Doris Duke Distinguished Clinical Scientist, and the Frederick G. L. Huetwell Professor.

\section{References}

1. Altshuler D, Daly MJ, Lander ES. Genetic mapping in human disease. Science 2008 Nov 7;322(5903):881-8. [PubMed: 18988837]

2. Machuca E, Benoit G, Antignac C. Genetics of nephrotic syndrome: connecting molecular genetics to podocyte physiology. Hum Mol Genet 2009 Oct 15;18(R2):R185-94. [PubMed: 19808795]

3. Kestila M, Mannikko M, Holmberg C, Tryggvason K, Peltonen L. Congenital nephrotic syndrome of the Finnish type is not associated with the Pax-2 gene despite the promising transgenic animal model. Genomics 1994 Feb;19(3):570-2. [PubMed: 8188301]

4. Boute N, Gribouval O, Roselli S, Benessy F, Lee H, Fuchshuber A, et al. NPHS2, encoding the glomerular protein podocin, is mutated in autosomal recessive steroid-resistant nephrotic syndrome. Nat Genet 2000 Apr;24(4):349-54. [PubMed: 10742096]

5. Karle SM, Uetz B, Ronner V, Glaeser L, Hildebrandt F, Fuchshuber A. Novel mutations in NPHS2 detected in both familial and sporadic steroid-resistant nephrotic syndrome. J Am Soc Nephrol 2002 Feb;13(2):388-93. [PubMed: 11805166]

6. Hinkes B, Wiggins RC, Gbadegesin R, Vlangos CN, Seelow D, Nurnberg G, et al. Positional cloning uncovers mutations in PLCE1 responsible for a nephrotic syndrome variant that may be reversible. Nat Genet 2006 Dec;38(12):1397-405. [PubMed: 17086182] 
7. Tryggvason K, Patrakka J, Wartiovaara J. Hereditary proteinuria syndromes and mechanisms of proteinuria. N Engl J Med 2006 Mar 30;354(13):1387-401. [PubMed: 16571882]

8. Wiggins RC. The spectrum of podocytopathies: a unifying view of glomerular diseases. Kidney Int 2007 Jun;71(12):1205-14. [PubMed: 17410103]

9. Heeringa SF, Moller CC, Du J, Yue L, Hinkes B, Chernin G, et al. A novel TRPC6 mutation that causes childhood FSGS. PLoS One 2009;4(11):e7771. [PubMed: 19936226]

10. Hinkes BG, Mucha B, Vlangos CN, Gbadegesin R, Liu J, Hasselbacher K, et al. Nephrotic syndrome in the first year of life: two thirds of cases are caused by mutations in 4 genes (NPHS1, NPHS2, WT1, and LAMB2). Pediatrics 2007 Apr;119(4):e907-19. [PubMed: 17371932]

11. Hinkes B, Vlangos C, Heeringa S, Mucha B, Gbadegesin R, Liu J, et al. Specific podocin mutations correlate with age of onset in steroid-resistant nephrotic syndrome. J Am Soc Nephrol 2008 Feb;19(2):365-71. [PubMed: 18216321]

12. Machuca E, Hummel A, Nevo F, Dantal J, Martinez F, Al-Sabban E, et al. Clinical and epidemiological assessment of steroid-resistant nephrotic syndrome associated with the NPHS2 R229Q variant. Kidney Int 2009 Apr;75(7):727-35. [PubMed: 19145239]

13. Ruf RG, Lichtenberger A, Karle SM, Haas JP, Anacleto FE, Schultheiss M, et al. Patients with mutations in NPHS2 (podocin) do not respond to standard steroid treatment of nephrotic syndrome. J Am Soc Nephrol 2004 Mar;15(3):722-32. [PubMed: 14978175]

14. Weber S, Gribouval O, Esquivel EL, Moriniere V, Tete MJ, Legendre C, et al. NPHS2 mutation analysis shows genetic heterogeneity of steroid-resistant nephrotic syndrome and low posttransplant recurrence. Kidney Int 2004 Aug;66(2):571-9. [PubMed: 15253708]

15. Torres VE, Harris PC, Pirson Y. Autosomal dominant polycystic kidney disease. Lancet 2007 Apr 14;369(9569):1287-301. [PubMed: 17434405]

16. Kim E, Walz G. Sensitive cilia set up the kidney. Nat Med 2007 Dec;13(12):1409-11. [PubMed: 18064029]

17. Torres VE, Harris PC. Autosomal dominant polycystic kidney disease: the last 3 years. Kidney Int 2009 Jul;76(2):149-68. [PubMed: 19455193]

18. Harris PC, Rossetti S. Molecular diagnostics of ADPKD coming of age. Clin J Am Soc Nephrol 2008 Jan;3(1):1-2. [PubMed: 18178778]

19. Smith C, Graham J. Congenital medullary cysts of the kidneys with severe refractory anemia. Am J Dis Child 1945;69:369-77.

20. Fanconi G, Hanhart E, Albertini A. Die familiäre juvenile Nephronophthise. Hel Pediatr Acta 1951;6:1-49.

21. Hildebrandt F, Zhou W. Nephronophthisis-associated ciliopathies. J Am Soc Nephrol 2007 Jun; 18(6):1855-71. [PubMed: 17513324]

22. Otto EA, Trapp ML, Schultheiss UT, Helou J, Quarmby LM, Hildebrandt F. NEK8 mutations affect ciliary and centrosomal localization and may cause nephronophthisis. J Am Soc Nephrol 2008 Mar;19(3):587-92. [PubMed: 18199800]

23. Attanasio M, Uhlenhaut NH, Sousa VH, O'Toole JF, Otto E, Anlag K, et al. Loss of GLIS2 causes nephronophthisis in humans and mice by increased apoptosis and fibrosis. Nat Genet 2007 Aug; 39(8):1018-24. [PubMed: 17618285]

24. Sayer JA, Otto EA, O'Toole JF, Nurnberg G, Kennedy MA, Becker C, et al. The centrosomal protein nephrocystin-6 is mutated in Joubert syndrome and activates transcription factor ATF4. Nat Genet 2006 Jun;38(6):674-81. [PubMed: 16682973]

25. Otto E, Loeys B, Khanna H, Hellemans J, Sudbrak R, Fan S, Muerb U, O’Toole JF, Helou J, Attanasio M, Utsch B, Sayer JA, Lillo C, Jimeno D, Coucke P, De Paepe A, Reinhardt R, Klages S, Tsuda M, Kawakami I, Kusakabe T, Omran H, Imm A, Tippens M, Raymond PA, Hill J, Beales P, He S, Kispert A, Margolis B, Williams DS, Swaroop A, Hildebrandt F. A novel ciliary IQ domain protein, NPHP5, is mutated in Senior-Loken syndrome (nephronophthisis with retinitis pigmentosa), and interacts with RPGR and calmodulin. Nat Genet 2005;37:282-8. [PubMed: 15723066]

26. Olbrich H, Fliegauf M, Hoefele J, Kispert A, Otto E, Volz A, et al. Mutations in a novel gene, NPHP3, cause adolescent nephronophthisis, tapeto-retinal degeneration and hepatic fibrosis. Nat Genet 2003 Aug;34(4):455-9. [PubMed: 12872122] 
27. Otto EA, Schermer B, Obara T, O_Toole JF, Hiller KS, Mueller AM, et al. Mutations in INVS encoding inversin cause nephronophthisis type 2, linking renal cystic disease to the function of primary cilia and left-right axis determination. Nat Genet 2003 Aug;34(4):413-20. [PubMed: 12872123]

28. Otto E, Hoefele J, Ruf R, Mueller AM, Hiller KS, Wolf MT, et al. A gene mutated in nephronophthisis and retinitis pigmentosa encodes a novel protein, nephroretinin, conserved in evolution. Am J Hum Genet 2002 Nov;71(5):1167-71.

29. Hildebrandt F, Otto E, Rensing C, Nothwang HG, Vollmer M, Adolphs J, et al. A novel gene encoding an SH3 domain protein is mutated in nephronophthisis type 1. Nat Genet 1997 Oct; 17(2):149-53. [PubMed: 9326933]

30. Mollet G, Salomon R, Gribouval O, Silbermann F, Bacq D, Landthaler G, et al. The gene mutated in juvenile nephronophthisis type 4 encodes a novel protein that interacts with nephrocystin. Nat Genet 2002 Oct;32(2):300-5. [PubMed: 12244321]

31. Delous M, Baala L, Salomon R, Laclef C, Vierkotten J, Tory K, et al. The ciliary gene RPGRIP1L is mutated in cerebello-oculo-renal syndrome (Joubert syndrome type B) and Meckel syndrome. Nat Genet 2007 Jul;39(7):875-81. [PubMed: 17558409]

32. Zaghloul NA, Katsanis N. Mechanistic insights into Bardet-Biedl syndrome, a model ciliopathy. J Clin Invest 2009 Mar;119(3):428-37. [PubMed: 19252258]

33. Stoetzel C, Laurier V, Davis EE, Muller J, Rix S, Badano JL, et al. BBS10 encodes a vertebratespecific chaperonin-like protein and is a major BBS locus. Nat Genet 2006 May;38(5):521-4. [PubMed: 16582908]

34. Kim JC, Ou YY, Badano JL, Esmail MA, Leitch CC, Fiedrich E, et al. MKKS/BBS6, a divergent chaperonin-like protein linked to the obesity disorder Bardet-Biedl syndrome, is a novel centrosomal component required for cytokinesis. J Cell Sci 2005 Mar 1;118(Pt 5):1007-20. [PubMed: 15731008]

35. Ye X, Dai J, Fang W, Jin W, Guo Y, Song J, et al. Cloning and characterization of a splice variant of human Bardet-Biedl syndrome 4 gene (BBS4). DNA Seq 2004 Jun;15(3):213-8. [PubMed: 15497446]

36. Badano JL, Ansley SJ, Leitch CC, Lewis RA, Lupski JR, Katsanis N. Identification of a novel Bardet-Biedl syndrome protein, BBS7, that shares structural features with BBS1 and BBS2. Am J Hum Genet 2003 Mar;72(3):650-8. [PubMed: 12567324]

37. Mykytyn K, Nishimura DY, Searby CC, Shastri M, Yen HJ, Beck JS, et al. Identification of the gene (BBS1) most commonly involved in Bardet-Biedl syndrome, a complex human obesity syndrome. Nat Genet 2002 Aug;31(4):435-8. [PubMed: 12118255]

38. Mykytyn K, Braun T, Carmi R, Haider NB, Searby CC, Shastri M, et al. Identification of the gene that, when mutated, causes the human obesity syndrome BBS4. Nat Genet 2001 Jun;28(2):188-91. [PubMed: 11381270]

39. Sheffield VC, Nishimura D, Stone EM. The molecular genetics of Bardet-Biedl syndrome. Curr Opin Genet Dev 2001 Jun;11(3):317-21. [PubMed: 11377969]

40. Nishimura DY, Searby CC, Carmi R, Elbedour K, Van Maldergem L, Fulton AB, et al. Positional cloning of a novel gene on chromosome 16q causing Bardet-Biedl syndrome (BBS2). Hum Mol Genet 2001 Apr 1;10(8):865-74. [PubMed: 11285252]

41. Slavotinek AM, Stone EM, Mykytyn K, Heckenlively JR, Green JS, Heon E, et al. Mutations in MKKS cause Bardet-Biedl syndrome. Nat Genet 2000 Sep;26(1):15-6. [PubMed: 10973238]

42. Katsanis N, Beales PL, Woods MO, Lewis RA, Green JS, Parfrey PS, et al. Mutations in MKKS cause obesity, retinal dystrophy and renal malformations associated with Bardet-Biedl syndrome. Nat Genet 2000 Sep;26(1):67-70. [PubMed: 10973251]

43. Hildebrandt F, Otto E. Cilia and centrosomes: a unifying pathogenic concept for cystic kidney disease? Nat Rev Genet 2005 Dec;6(12):928-40. [PubMed: 16341073]

44. Watnick T, Germino G. From cilia to cyst. Nat Genet 2003 Aug;34(4):355-6. [PubMed: 12923538]

45. Hildebrandt F, Attanasio M, Otto E. Nephronophthisis: disease mechanisms of a ciliopathy. J Am Soc Nephrol 2009 Jan;20(1):23-35. [PubMed: 19118152] 
46. Igarashi P, Somlo S. Genetics and pathogenesis of polycystic kidney disease. J Am Soc Nephrol 2002 Sep;13(9):2384-98. [PubMed: 12191984]

47. Fischer E, Legue E, Doyen A, Nato F, Nicolas JF, Torres V, et al. Defective planar cell polarity in polycystic kidney disease. Nat Genet 2006 Jan;38(1):21-3. [PubMed: 16341222]

48. Baala L, Audollent S, Martinovic J, Ozilou C, Babron MC, Sivanandamoorthy S, et al. Pleiotropic effects of CEP290 (NPHP6) mutations extend to Meckel syndrome. Am J Hum Genet 2007 Jul; 81(1):170-9. [PubMed: 17564974]

49. Hoefele J, Wolf MT, O’Toole JF, Otto EA, Schultheiss U, Deschenes G, et al. Evidence of oligogenic inheritance in nephronophthisis. J Am Soc Nephrol 2007 Oct;18(10):2789-95. [PubMed: 17855640]

50. Leitch CC, Zaghloul NA, Davis EE, Stoetzel C, Diaz-Font A, Rix S, et al. Hypomorphic mutations in syndromic encephalocele genes are associated with Bardet-Biedl syndrome. Nat Genet. 2008 Mar 9;

51. Henske EP. The genetic basis of kidney cancer: why is tuberous sclerosis complex often overlooked? Curr Mol Med 2004 Dec;4(8):825-31. [PubMed: 15579029]

52. Simon DB, Lifton RP. The molecular basis of inherited hypokalemic alkalosis: Bartter's and Gitelman's syndromes. Am J Physiol 1996 Nov;271(5 Pt 2):F961-6. [PubMed: 8945989]

53. Simon DB, Karet FE, Rodriguez-Soriano J, Hamdan JH, DiPietro A, Trachtman H, et al. Genetic heterogeneity of Bartter's syndrome revealed by mutations in the K+ channel, ROMK. Nat Genet 1996 Oct;14(2):152-6. [PubMed: 8841184]

54. Simon DB, Karet FE, Hamdan JM, DiPietro A, Sanjad SA, Lifton RP. Bartter's syndrome, hypokalaemic alkalosis with hypercalciuria, is caused by mutations in the $\mathrm{Na}-\mathrm{K}-2 \mathrm{Cl}$ cotransporter NKCC2. Nat Genet 1996 Jun;13(2):183-8. [PubMed: 8640224]

55. Birkenhager R, Otto E, Schurmann MJ, Vollmer M, Ruf EM, Maier-Lutz I, et al. Mutation of BSND causes Bartter syndrome with sensorineural deafness and kidney failure. Nat Genet 2001 Nov;29(3):310-4. [PubMed: 11687798]

56. Estevez R, Boettger T, Stein V, Birkenhager R, Otto E, Hildebrandt F, et al. Barttin is a Clchannel beta-subunit crucial for renal Cl- reabsorption and inner ear $\mathrm{K}+$ secretion. Nature 2001 Nov 29;414(6863):558-61. [PubMed: 11734858]

57. Simon DB, Bindra RS, Mansfield TA, Nelson-Williams C, Mendonca E, Stone R, et al. Mutations in the chloride channel gene, CLCNKB, cause Bartter's syndrome type III. Nat Genet 1997 Oct; 17(2):171-8. [PubMed: 9326936]

58. Simon DB, Nelson-Williams C, Bia MJ, Ellison D, Karet FE, Molina AM, et al. Gitelman's variant of Bartter's syndrome, inherited hypokalaemic alkalosis, is caused by mutations in the thiazidesensitive Na-Cl cotransporter. Nat Genet 1996 Jan;12(1):24-30. [PubMed: 8528245]

59. Glaudemans B, van der Wijst J, Scola RH, Lorenzoni PJ, Heister A, van der Kemp AW, et al. A missense mutation in the Kv1.1 voltage-gated potassium channel-encoding gene KCNA1 is linked to human autosomal dominant hypomagnesemia. J Clin Invest 2009 Apr;119(4):936-42. [PubMed: 19307729]

60. Knoers NV. Inherited forms of renal hypomagnesemia: an update. Pediatr Nephrol 2009 Apr; 24(4):697-705. [PubMed: 18818955]

61. Konrad M, Schlingmann KP, Gudermann T. Insights into the molecular nature of magnesium homeostasis. Am J Physiol Renal Physiol 2004 Apr;286(4):F599-605. [PubMed: 15001450]

62. Deen PM, Verdijk MA, Knoers NV, Wieringa B, Monnens LA, van Os CH, et al. Requirement of human renal water channel aquaporin-2 for vasopressin-dependent concentration of urine. Science 1994 Apr 1;264(5155):92-5. [PubMed: 8140421]

63. Rosenthal W, Seibold A, Antaramian A, Lonergan M, Arthus MF, Hendy GN, et al. Molecular identification of the gene responsible for congenital nephrogenic diabetes insipidus. Nature 1992 Sep 17;359(6392):233-5. [PubMed: 1356229]

64. Bichet DG, Hendy GN, Lonergan M, Arthus MF, Ligier S, Pausova Z, et al. X-linked nephrogenic diabetes insipidus: from the ship Hopewell to RFLP studies. Am J Hum Genet 1992 Nov;51(5): 1089-102. [PubMed: 1357965]

65. Sayer JA. The genetics of nephrolithiasis. Nephron Exp Nephrol 2008;110(2):e37-43. [PubMed: 18758188] 
66. Pohl M, Bhatnagar V, Mendoza SA, Nigam SK. Toward an etiological classification of developmental disorders of the kidney and upper urinary tract. Kidney Int 2002 Jan;61(1):10-9. [PubMed: 11786080]

67. Woolf AS. A molecular and genetic view of human renal and urinary tract malformations. Kidney Int 2000 Aug;58(2):500-12. [PubMed: 10916073]

68. Chen F. Genetic and developmental basis for urinary tract obstruction. Pediatr Nephrol 2009 Sep; 24(9):1621-32. [PubMed: 19085015]

69. Skinner MA, Safford SD, Reeves JG, Jackson ME, Freemerman AJ. Renal aplasia in humans is associated with RET mutations. Am J Hum Genet 2008 Feb;82(2):344-51. [PubMed: 18252215]

70. Jenkins D, Bitner-Glindzicz M, Malcolm S, Hu CC, Allison J, Winyard PJ, et al. De novo Uroplakin IIIa heterozygous mutations cause human renal adysplasia leading to severe kidney failure. J Am Soc Nephrol 2005 Jul;16(7):2141-9. [PubMed: 15888565]

71. Weber S, Taylor JC, Winyard P, Baker KF, Sullivan-Brown J, Schild R, et al. SIX2 and BMP4 mutations associate with anomalous kidney development. J Am Soc Nephrol 2008 May;19(5): 891-903. [PubMed: 18305125]

72. Groenen PM, Vanderlinden G, Devriendt K, Fryns JP, Van de Ven WJ. Rearrangement of the human CDC5L gene by a $\mathrm{t}(6 ; 19)(\mathrm{p} 21 ; \mathrm{q} 13.1)$ in a patient with multicystic renal dysplasia. Genomics 1998 Apr 15;49(2):218-29. [PubMed: 9598309]

73. Lu W, van Eerde AM, Fan X, Quintero-Rivera F, Kulkarni S, Ferguson H, et al. Disruption of $\mathrm{ROBO} 2$ is associated with urinary tract anomalies and confers risk of vesicoureteral reflux. Am J Hum Genet 2007 Apr;80(4):616-32. [PubMed: 17357069]

74. Kuwayama F, Miyazaki Y, Ichikawa I. Embryogenesis of the congenital anomalies of the kidney and the urinary tract. Nephrol Dial Transplant 2002;17( Suppl 9):45-7. [PubMed: 12386286]

75. Nakano T, Niimura F, Hohenfellner K, Miyakita E, Ichikawa I. Screening for mutations in BMP4 and FOXC1 genes in congenital anomalies of the kidney and urinary tract in humans. Tokai J Exp Clin Med 2003 Oct;28(3):121-6. [PubMed: 15055404]

76. Grieshammer U, Le M, Plump AS, Wang F, Tessier-Lavigne M, Martin GR. SLIT2-mediated ROBO2 signaling restricts kidney induction to a single site. Dev Cell 2004 May;6(5):709-17. [PubMed: 15130495]

77. Sanyanusin P, McNoe LA, Sullivan MJ, Weaver RG, Eccles MR. Mutation of PAX2 in two siblings with renal-coloboma syndrome. Hum Mol Genet 1995 Nov;4(11):2183-4. [PubMed: 8589702]

78. McGregor L, Makela V, Darling SM, Vrontou S, Chalepakis G, Roberts C, et al. Fraser syndrome and mouse blebbed phenotype caused by mutations in FRAS1/Fras1 encoding a putative extracellular matrix protein. Nat Genet 2003 Jun;34(2):203-8. [PubMed: 12766769]

79. Vrontou S, Petrou P, Meyer BI, Galanopoulos VK, Imai K, Yanagi M, et al. Fras1 deficiency results in cryptophthalmos, renal agenesis and blebbed phenotype in mice. Nat Genet 2003 Jun; 34(2):209-14. [PubMed: 12766770]

80. Van Esch H, Groenen P, Nesbit MA, Schuffenhauer S, Lichtner P, Vanderlinden G, et al. GATA3 haplo-insufficiency causes human HDR syndrome. Nature 2000 Jul 27;406(6794):419-22. [PubMed: 10935639]

81. Abdelhak S, Kalatzis V, Heilig R, Compain S, Samson D, Vincent C, et al. A human homologue of the Drosophila eyes absent gene underlies branchio-oto-renal (BOR) syndrome and identifies a novel gene family. Nat Genet 1997 Feb;15(2):157-64. [PubMed: 9020840]

82. Ruf RG, Xu PX, Silvius D, Otto EA, Beekmann F, Muerb UT, et al. SIX1 mutations cause branchio-oto-renal syndrome by disruption of EYA1-SIX1-DNA complexes. Proc Natl Acad Sci U S A 2004 May 25;101(21):8090-5. [PubMed: 15141091]

83. Hoskins BE, Cramer CH, Silvius D, Zou D, Raymond RM, Orten DJ, et al. Transcription factor SIX5 is mutated in patients with branchio-oto-renal syndrome. Am J Hum Genet 2007 Apr;80(4): 800-4. [PubMed: 17357085]

84. Kohlhase J, Wischermann A, Reichenbach H, Froster U, Engel W. Mutations in the SALL1 putative transcription factor gene cause Townes-Brocks syndrome. Nat Genet 1998 Jan;18(1):813. [PubMed: 9425907] 
85. Reidy KJ, Rosenblum ND. Cell and molecular biology of kidney development. Semin Nephrol 2009 Jul;29(4):321-37. [PubMed: 19615554]

86. Dressler GR. The cellular basis of kidney development. Annu Rev Cell Dev Biol 2006;22:509-29. [PubMed: 16822174]

87. Schedl A. Renal abnormalities and their developmental origin. Nat Rev Genet 2007 Oct;8(10): 791-802. [PubMed: 17878895]

88. Ichikawa I, Kuwayama F, Pope JCt, Stephens FD, Miyazaki Y. Paradigm shift from classic anatomic theories to contemporary cell biological views of CAKUT. Kidney Int 2002 Mar;61(3): 889-98. [PubMed: 11849443]

89. Locke JM, Ellard S, Norwood VF, Harries LW. Variants in the isoform-specific coding regions of the HNF1A, HNF4A and HNF1B genes are not a common cause of familial, young-onset diabetes or renal cysts and diabetes (RCAD). Diabet Med 2009 May;26(5):569-70. [PubMed: 19646202]

90. Kiefer SM, Ohlemiller KK, Yang J, McDill BW, Kohlhase J, Rauchman M. Expression of a truncated Sall1 transcriptional repressor is responsible for Townes-Brocks syndrome birth defects. Hum Mol Genet 2003 Sep 1;12(17):2221-7. [PubMed: 12915476]

91. Badano JL, Leitch CC, Ansley SJ, May-Simera H, Lawson S, Lewis RA, et al. Dissection of epistasis in oligogenic Bardet-Biedl syndrome. Nature 2006 Jan 19;439(7074):326-30. [PubMed: 16327777]

92. Tory K, Lacoste T, Burglen L, Moriniere V, Boddaert N, Macher MA, et al. High NPHP1 and NPHP6 mutation rate in patients with Joubert syndrome and nephronophthisis: potential epistatic effect of NPHP6 and AHI1 mutations in patients with NPHP1 mutations. J Am Soc Nephrol 2007 May;18(5):1566-75. [PubMed: 17409309]

93. Kopp JB, Smith MW, Nelson GW, Johnson RC, Freedman BI, Bowden DW, et al. MYH9 is a major-effect risk gene for focal segmental glomerulosclerosis. Nat Genet 2008 Oct;40(10):117584. [PubMed: 18794856]

94. Kao WH, Klag MJ, Meoni LA, Reich D, Berthier-Schaad Y, Li M, et al. MYH9 is associated with nondiabetic end-stage renal disease in African Americans. Nat Genet 2008 Oct;40(10):1185-92. [PubMed: 18794854]

95. Shimazaki A, Kawamura Y, Kanazawa A, Sekine A, Saito S, Tsunoda T, et al. Genetic variations in the gene encoding ELMO1 are associated with susceptibility to diabetic nephropathy. Diabetes 2005 Apr;54(4):1171-8. [PubMed: 15793258]

96. Divers J, Freedman BI. Susceptibility genes in common complex kidney disease. Curr Opin Nephrol Hypertens. 2009 Oct 15;

97. Hodges E, Xuan Z, Balija V, Kramer M, Molla MN, Smith SW, et al. Genome-wide in situ exon capture for selective resequencing. Nat Genet 2007 Dec;39(12):1522-7. [PubMed: 17982454] 


\section{Table 1}

Degrees of genetic causality and power of molecular genetic diagnostics in recessive, dominant and polygenic diseases.

\begin{tabular}{llll}
\hline & & Monogenic & Polygenic \\
\cline { 2 - 4 } & Recessive & Dominant & Weak \\
\hline Genetic causality & Strong & Intermediate & Weak \\
\hline Penetrance & Full & Sometimes incomplete & Weak \\
\hline Predictive power of mutation analysis & Almost 100\% & Strong $a$ & Adolescent, adult \\
\hline Age of onset & Fetus, child, adolescent & Adult & Only assignment of \\
Molecular genetic approaches & $\begin{array}{l}\text { Direct exon sequencing of known } \\
\text { disease genes }\end{array}$ & $\begin{array}{l}\text { Direct exon sequencing of } \\
\text { known disease genes }\end{array}$ & $<1: 5$ (frequent) \\
\hline Frequency & $<1: 40,000$ (rare) & $<1: 1,000$ (rare) & $\begin{array}{l}\text { Genome wide association } \\
\text { studies (GWAS) }\end{array}$ \\
\hline Data usually derived from & $\begin{array}{l}\text { Gene mapping and gene } \\
\text { identification }\end{array}$ & $\begin{array}{l}\text { Gene mapping and gene } \\
\text { identification }\end{array}$ & Difficult \\
\hline Confirmation by animal model & Very feasible & Feasible & \\
\hline
\end{tabular}

${ }^{a}$ Except for incomplete penetrance and variable expressivity 
Table 2

Single-gene glomerular diseases. (The leading diagnostic feature is proteinuria).

\begin{tabular}{|c|c|c|c|c|}
\hline GLOMERULAR DISEASES & OMIM No. & MOI & $\begin{array}{l}\text { Characteristic signs and } \\
\text { features }\end{array}$ & Gene symbol(s), gene product(s) \\
\hline Congenital SRNS (Finnish type) & $\# 256300$ & $\mathrm{AR}$ & $\begin{array}{l}\text { congenital nephrotic syndrome, } \\
\text { CKD }\end{array}$ & NPHS1, nephrin \\
\hline SRNS type 2 & \#600995 & $\mathrm{AR}$ & SRNS, FSGS, CKD & NPHS2, podocin \\
\hline SRNS type 3 & \#610725 & $\mathrm{AR}$ & $\begin{array}{l}\text { SRNS (SSNS), DMS, FSGS, } \\
\text { CKD }\end{array}$ & PLCE1, phospholipase C \\
\hline SRNS type 4 & \#600995 & $\mathrm{AR},(\mathrm{AD})$ & SRNS, FSGS & $C D 2 A P, \mathrm{CD} 2 \mathrm{AP}$ \\
\hline Pierson syndrome & $\# 609049$ & $\mathrm{AR}$ & SRNS and microcoria & $L A M B 2$, laminin- $\beta 2$ \\
\hline SRNS, adult-onset & \#600995 & $\mathrm{AD}$ & Adult-onset SRNS, FSGS, CKD & NPHS2, $\alpha$-actinin-4 (ACTN4) \\
\hline SRNS, adult-onset & $\# 603965$ & $\mathrm{AD}$ & Adult-onset SRNS, FSGS, CKD & $\begin{array}{l}\text { TRPC6, transient receptor } \\
\text { potential cation channel C6 }\end{array}$ \\
\hline $\begin{array}{l}\text { Denys-Drash syndrome, Frasier } \\
\text { syndrome }\end{array}$ & \#194080 & $\mathrm{AD}$ & $\begin{array}{l}\text { Wilms' tumour, } \\
\text { pseudohermaphroditism, } \\
\text { nephrotic syndrome }\end{array}$ & $W T 1$, WT suppressor gene \\
\hline Nail-Patella syndrome & \#161200 & $\mathrm{AD}$ & $\begin{array}{l}\text { Nail dysplasia, absent patella, } \\
\text { SRNS }\end{array}$ & $\begin{array}{l}L M X 1 B, \text { LIM homeodomain } \\
\text { protein }\end{array}$ \\
\hline Schimke immuno-osseous dystrophy & $\# 242900$ & $\mathrm{AR}$ & $\begin{array}{l}\text { Bone abnormalities, } \\
\text { immunodeficiency, SRNS }\end{array}$ & $\begin{array}{l}\text { SMARCAL1, HepA-related } \\
\text { protein (HARP) }\end{array}$ \\
\hline Mitochondrial disorders with SRNS & \#607426 & $\mathrm{AR}$ & $\begin{array}{l}\text { SRNS +/- neurologic } \\
\text { impairment/SND }\end{array}$ & COQ2, PDSS2, MTTL1 \\
\hline Lysosomal disorders with SRNS & \#254900 & AR & Action myoclonus, SRNS, CKD & $\begin{array}{l}S C A R B 2 \text {, lysosomal integral } \\
\text { membrane protein (LIMP2) }\end{array}$ \\
\hline $\begin{array}{l}\text { Glomerulopathy with fibronection } \\
\text { deposits }\end{array}$ & \#601894 & $\mathrm{AD}$ & Proteinuria, dRTA & $F N 1$, fibronectin-1 \\
\hline Alport syndrom & $\# 301050$ & $\mathrm{XD}$ & Nephritis, SND, CKD & COL4A5, $\alpha 5(\mathrm{IV})$-collagen \\
\hline Alport syndrom with leiomyomatosis & \#308940 & $\mathrm{XD}$ & $\begin{array}{l}\text { Alport syndrom with } \\
\text { leiomyomatosis, CKD }\end{array}$ & COL4A6, $\alpha 6$ (IV)-collagen \\
\hline Alport syndrom & \#203780 & $\mathrm{AR}$ & $\begin{array}{l}\text { Alport syndrome or benign } \\
\text { familial hematuria }\end{array}$ & COLAA3, $\alpha 3$ (IV)-collagen \\
\hline Alport syndrom & $* 120131$ & $\mathrm{AR}$ & Nephritis, SND, CKD & COL4A4, $\alpha 4$ (IV)-collagen \\
\hline
\end{tabular}

$\mathrm{AD}=$ autosomal dominant, $\mathrm{AR}=$ autosomal recessive, $\mathrm{CKD}=$ chronic kidney disease, $\mathrm{DMS}=$ diffuse mesangial sclerosis, FSGS=focal segmental glomerulosclerosis, MOI=mode of inheritance, SND =sensorineural deafness, SSNS=steroid sensitive nephrotic syndrome, SRNS=steroid resistant nephrotic syndrome, $\mathrm{XD}=\mathrm{X}$-linked dominant 


\section{Table 3}

Renal cystic, interstitial and tumorous kidney diseases. (The leading diagnostic features are renal ultrasound findings of cysts, increased echogenicity, or tumor, respectively).

\begin{tabular}{|c|c|c|c|c|}
\hline $\begin{array}{l}\text { CYSTIC, INTERSTITIAL AND } \\
\text { TUMOROUS KIDNEY DISEASES }\end{array}$ & OMIM No. & MOI & Characteristic signs and features & Gene symbol(s), gene product(s) \\
\hline ADPKD, type 1 & \#601313 & $\mathrm{AD}$ & $\begin{array}{l}\text { Polycystic kidneys, liver cysts, } \\
\text { brain aneurysms, CKD }\end{array}$ & $P K D 1$, polycystin 1 \\
\hline ADPKD, type 2 & \#173910 & $\mathrm{AD}$ & Polycystic kidneys, CKD & $P K D 2$, polycystin 2 \\
\hline ARPKD & \#263200 & AR & $\begin{array}{l}\text { Polycystic kidneys, liver fibrosis, } \\
\text { CKD }\end{array}$ & PKHD1, fibrocystin/polyductin \\
\hline Nephronophthisis types $1-9$ & $\# 256100$ & $\mathrm{AR}$ & Polyuria, polydipsia, anemia, CKD & NPHP1-NPHP9, nephrocystin 1-9 \\
\hline Medullary cystic kidney disease & $\# 174000$ & $\mathrm{AD}$ & $\begin{array}{l}\text { Adult onset CKD, hyperuricemia, } \\
\text { FJHN }\end{array}$ & $U M O D$, Tamm-Horsfall protein \\
\hline Meckel-Gruber syndrome (MKS) & $\begin{array}{l}\# 249000 \\
\# 607361\end{array}$ & AR & $\begin{array}{l}\text { Polycystic kidneys, multiple organ } \\
\text { dysplasia, perinatal lethal }\end{array}$ & $\begin{array}{l}M K S 1 ; M K S 3, \text { meckelin (also allelic } \\
\text { with NPHP genes) }\end{array}$ \\
\hline Bardet-Biedl syndrome types $1-12$ & \#209900 & $\mathrm{AR}$ & $\begin{array}{l}\text { Retinitis pigmentosa, polydactyly, } \\
\text { MR, hypogenitalism and obesity }\end{array}$ & $B B S 1-B B S 12$, BBS proteins \\
\hline Tuberous sclerosis types 1 and 2 & $\begin{array}{l}\# 191100 \\
\# 191092\end{array}$ & $\mathrm{AD}$ & $\begin{array}{l}\text { Renal angiomyolipomas, skin } \\
\text { changes, seizures }\end{array}$ & $\begin{array}{l}T S C 1, \text { hamartin } \\
T S C 2, \text { tuberin }\end{array}$ \\
\hline von-Hippel-Lindau disease & \#193300 & $\mathrm{AD}$ & $\begin{array}{l}\text { Lindau tumor, retinal } \\
\text { angiomatosis, pheochromocytoma, } \\
\text { renal tumor }\end{array}$ & $V H L$, Tumor suppressor gene g7 \\
\hline Wilms-tumor-aniridia syndrome & \#194072 & $\mathrm{AD}$ & $\begin{array}{l}\text { Wilms tumour, aniridia, growth } \\
\text { retardation }\end{array}$ & WT1, WT suppressor gene \\
\hline Papillary renal cell carcinoma & \#164860 & $\mathrm{AD}$ & Papillary renal cell carcinoma & $M E T$ gene, protooncogen \\
\hline
\end{tabular}

$\mathrm{ADPKD}=$ autosomal dominant polycystic kidney disease, $\mathrm{AD}=$ autosomal dominant, $\mathrm{AR}=$ autosomal recessive, $\mathrm{CNV}=\mathrm{central}$ nervous system, $\mathrm{FJHN}=$ familial juvenile hyperuricemic nephropathy, $\mathrm{MR}=$ mental retardation, $\mathrm{XR}=\mathrm{X}$-linked recessive 


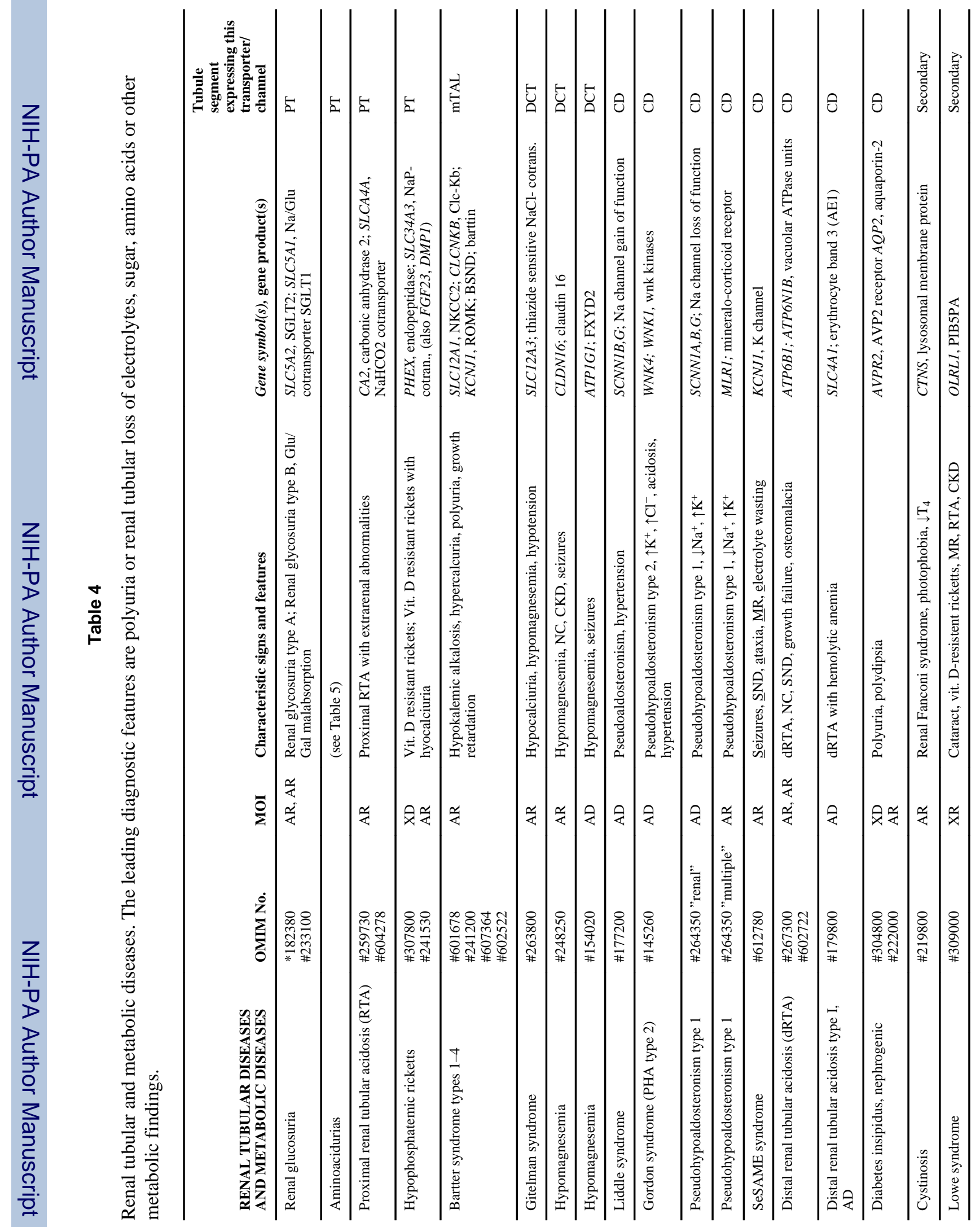




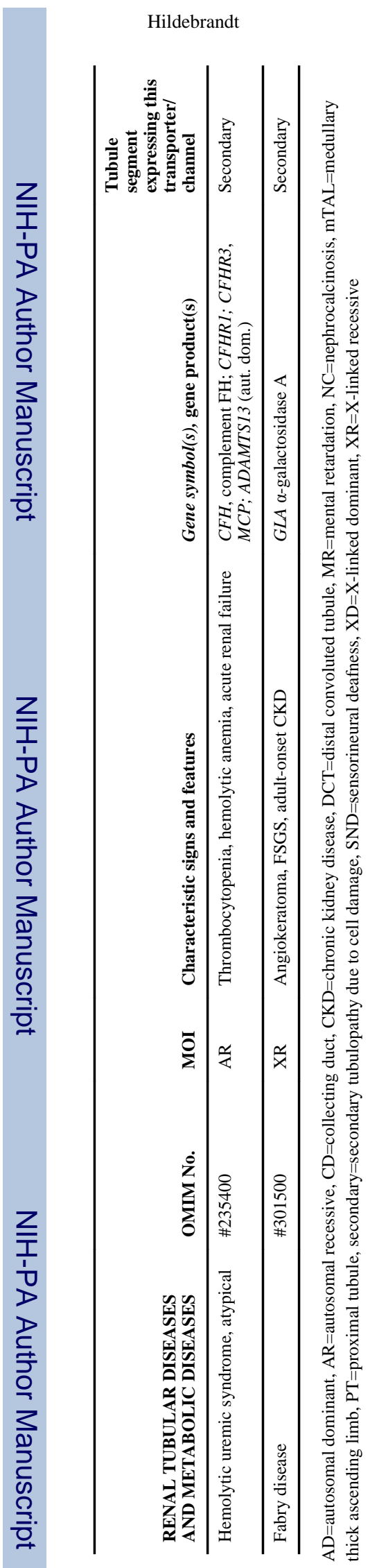

Page 17 
Table 5

Nephrolithiasis. The leading diagnostic features are renal calculi or nephrocalcinosis.

\begin{tabular}{lllll}
\hline NEPHROLITHIASIS & OMIM No. & MOI & $\begin{array}{l}\text { Characteristic signs } \\
\text { and features }\end{array}$ & Gene symbol, gene product \\
\hline Cystinuria, type 1 & $\# 220100$ & AR & Cystin calculi & CSNU1, SLC3A1 amino acid transporter \\
\hline Cystinuria, non-type 1 & $\# 604144$ & AR & Cystin calculi & SLC7A9, amino acid transporter \\
\hline Dent disease & $\# 300009$ & XR & $\begin{array}{l}\text { NL, NC, renal Fanconi } \\
\text { syndrome }\end{array}$ & CLCN5, renal Cl-Channel \\
\hline Primary hyperoxaluria type 1 & $\# 259900$ & AR & NL, CKD & AGXT, Ala-glyoxylate aminotransferase \\
\hline Primary hyperoxaluria type 2 & $\# 260000$ & AR & NL & GRHPR, glyoxylate reductase \\
\hline Lysinuric protein intolerance & $\# 222700$ & AD & $\begin{array}{l}\text { NL, phosphate wasting, } \\
\text { osteopenia }\end{array}$ & SLC9A3R1, NHERF1 \\
\hline Adenine-phosphoribosyl-transferase deficiency & $\# 102600$ & AR & NL & APR5, adenine phosphoribosyl transferase \\
\hline Xanthinuria & $\# 278300$ & AR & NL, xanthine calculi & XHD, xanthin dehydrogenase \\
\hline Distal renal tubular acidosis & $\# 179800$ & AD & NL, ricketts & SLC4A1, RTA \\
\hline
\end{tabular}

$\mathrm{AD}=$ autosomal dominant, $\mathrm{AR}=$ autosomal recessive, $\mathrm{NC}=$ nephrocalcinosis, $\mathrm{NL}=$ nephrolithiasis, $\mathrm{RTA}=\mathrm{renal}$ tubular acidosis, $\mathrm{XR}=\mathrm{X}$-linked recessive 


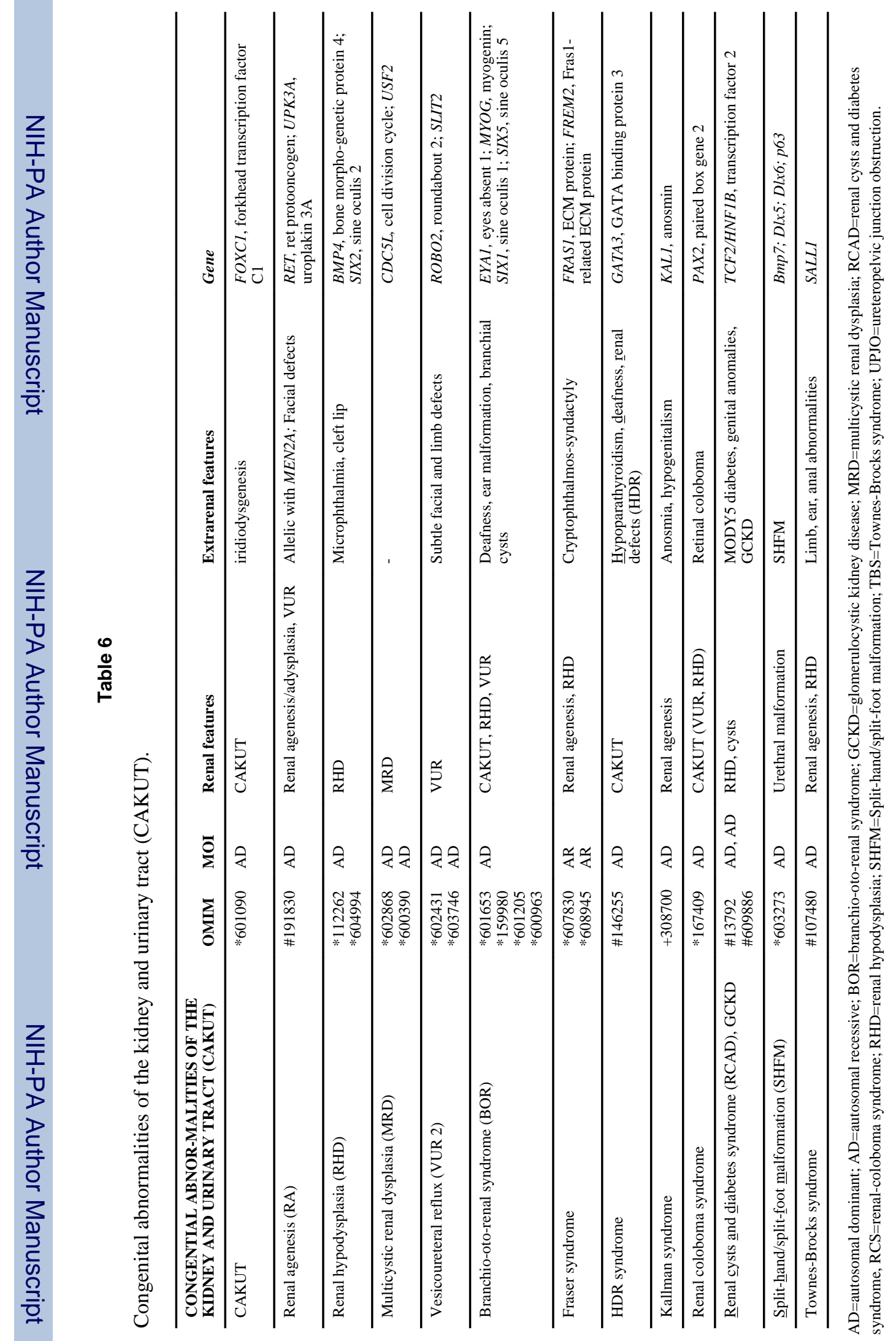

